\title{
Y 90 Monoclonal Antibody m170
}

National Cancer Institute

\section{Source}

National Cancer Institute. Y 90 Monoclonal Antibody m170. NCI Thesaurus. Code C2532.

A radioimmunoconjug ate of $\mathrm{m} 170$ monoclonal antibody (MoAb) conjug ated with isotope yttrium 90. MoAb m170 is a murine MoAb that recognizes MUC-1 antigen present on the surface of many adenocarcinomas. This radioimmunoconjug ate emits beta particles that cause cytotoxicity in tumor cells and has both imaging and therapeutic uses. 